\title{
Mutation analysis of the p53, APC, and p16 genes in the Barrett's oesophagus, dysplasia, and adenocarcinoma
}

\author{
María Victoria González, Manuel L Artímez, Luis Rodrigo, Carlos López-Larrea, \\ María J Menéndez, Victoria Alvarez, Ramón Pérez, Manuel F Fresno, María J Pérez, \\ Andrés Sampedro, Eliecer Coto
}

Hospital Central de Asturias, Oviedo, Spain:

Laboratorio de Genética

Molecular-Servicio de Inmunología

M V González

C López-Larrea

M J Menéndez

V Alvarez

E Coto

Servicio de Digestivo M L Artímez

R Pérez

L Rodrigo

Servicio de Anatomía Patológica

M F Fresno

M J Pérez

A Sampedro

Correspondence to:

Dr Eliecer Coto, Servicio de Inmunología, Hospital Central de Asturias, 33006 Oviedo, Spain.

Accepted for publication 10 December 1996

\begin{abstract}
Aims-To study the loss of heterozygosity and the presence of mutations at the p53, p16/CDKN2, and APC genes in Barrett's oesophagus, low grade dysplastic oesophageal epithelium, and adenocarcinoma of the oesophagus; to relate the presence of alterations at these genes with the progression from Barrett's oesophagus to adenocarcinoma.

Methods-DNA was extracted from paraffin blocks containing tissue from Barrett's oesophagus (12 samples), low grade dysplasia (15 cases), and adenocarcinoma (14 cases). Loss of heterozygosity (LOH) at the p53, p16, and APC genes was determined by comparing the autoradiographic patterns of several microsatellite markers between the normal tissue and the malignant tissue counterpart. SSCP was used to determine the presence of mutations at p53 (exons 5 to 8), p16 (exon 2), and APC. Homozygous deletion of the p16 gene was defined through polymerase chain reaction followed by Southern blot. Results-LOH at the p53, p16, and APC genes was not observed in Barrett's oesophagus without dysplasia, and increased to $90 \%$ (p53), $89 \%$ (p16), and $60 \%$ (APC) in the adenocarcinomas. The p53 gene was mutated in only two adenocarcinomas (codons 175 and 245). In one case a mutation at the APC gene (codon 1297) was found. No patient had mutation at the second exon of p16. However, this gene was homozygously deleted in three of the 12 adenocarcinomas.
\end{abstract}

Conclusions-The tumour suppressor genes p53, p16, and APC are often deleted in adenocarcinomas derived from Barrett's oesophagus. Mutations at these genes are also found in the adenocarcinomas, including the homozygous deletion of the p16 gene. However, the absence of genetic alterations in the Barrett's oesophagus and the low grade dysplastic epithelia suggest that mutations at these genes develop later in the progression from Barrett's oesophagus to adenocarcinoma.

(F Clin Pathol 1997;50:212-217)

Keywords: Barrett's oesophagus; tumour suppressor genes; loss of heterozygosity; single strand conformation polymorphism.
Barrett's oesophagus develops as a result of chronic gastro-oesophageal reflux, leading to the replacement of normal stratified squamous epithelium of the oesophagus by metaplastic columnar epithelium. ${ }^{1}$ In the USA the number of cases of Barrett's oesophagus has been estimated to be two million. ${ }^{2}$ Within 10 years, $10 \%$ of patients with Barrett's oesophagus progress to oesophageal adenocarcinoma by a multistep process morphologically defined as metaplasia $\rightarrow$ low grade dysplasia $\rightarrow$ high grade dysplasia $\rightarrow$ adenocarcinoma. Barrett's epithelium can be detected and biopsied by endoscopy. ${ }^{3}$ Oesophagectomy can be performed curatively in these patients. Most patients are subjected to periodic biopsy for the early detection of cancer. ${ }^{4}$ Patients with high grade dysplasia or early carcinoma have a favourable prognosis after the malignant epithelium is surgically removed. ${ }^{56}$ In addition to cancer epithelium, the surrounding premalignant epithelium is also removed, thus allowing study of molecular alterations involved in neoplastic progression. Several groups have defined a central role of p53 in this cancer, suggesting that abnormalities at this tumour suppressor gene occur as an early event in the progression to adenocarcinoma. ${ }^{7-12}$ Cells from normal epithelium contain two normal (wild type) copies of p53, while in most of the patients both copies of p53 in the high grade dysplastic epithelium were inactivated through allelic loss and mutation. ${ }^{713}$ Inactivation of the p53 gene is followed by the development of aneuploidy. ${ }^{8}$ Flow cytometry measurement of DNA content abnormalities has now been established as a marker for risk of progression to cancer. ${ }^{14}{ }^{15}$ Patients with a normal diploid epithelium have a very low risk of progressing to cancer. ${ }^{15} 16$ Allelic losses of $5 \mathrm{q}$ have been detected in several human solid tumours, including oesophagus and colon. ${ }^{17} 18$ This chromosomal region harbours the APC gene, a tumour suppressor frequently mutated in colon carcinoma. Loss of heterozygosity $(\mathrm{LOH})$ at APC has been described in Barrett's adenocarcinomas. In all cases, $\mathrm{LOH}$ at p53 precedes $\mathrm{LOH}$ at APC. ${ }^{19}$

Another tumour suppressor gene, p16/ CDKN2/MTS1, is often involved in the development of most human cancers. ${ }^{20}$ This gene maps to chromosome $9 \mathrm{p} 21$, a region of common deletion in several cancer types, including oesophageal carcinomas. ${ }^{21} \mathrm{CDKN} 2$ 
is a protein that forms binary complexes with the cyclin dependent kinases Cdk4 and Cdk6, inhibiting their ability to phosphorylate the retinoblastoma protein ( $\mathrm{pRB}){ }^{22}$ Unphosphorylated $\mathrm{pRB}$ prevents the cell from entering the cell cycle. Thus loss of p16 allows the cell to grow and divide, a characteristic of cancer. Loss of the p16 function occurs through three major mechanisms: nucleotide mutation, gene deletion, and loss of expression after methylation of a $\mathrm{CpG}$ island located at the 5 ' region of the gene. ${ }^{23-27}$

We have studied the p53, APC, and p16 genes in several cases of Barrett's oesophagus with different grades of dysplasia and Barrett's derived adenocarcinomas. Our aim was to establish the role of mutations at these genes in the origin and progression of this malignancy.

\section{Methods}

TISSUE SAMPLES AND PATHOLOGICAL ANALYSIS Oesophageal epithelium was obtained from endoscopic biopsies or oesophagectomy samples. The whole tissue sample was embedded in paraffin, sectioned into $4 \mu \mathrm{m}$ slices, and analysed for histopathological classification. Samples were classified as previously described as negative for dysplasia, low grade dysplasia, and adenocarcinoma. ${ }^{34}$ Patients with adenocarcinoma had not received chemotherapy or radiation before surgery. For each patient, microdissections containing epithelium with more than $75 \%$ metaplastic or Barrett's cells were prepared. Microdissections consisting of the normal surrounding mucosa were also prepared.

\section{DNA EXTRACTIONS}

DNA was extracted from tissue slices containing the abnormal epithelium and from the normal epithelium counterpart. Briefly, each 10 $\mu \mathrm{m}$ slice was placed in a $1.5 \mathrm{ml}$ Eppendorf tube and incubated overnight at $52^{\circ} \mathrm{C}$ in $0.5 \mathrm{ml}$ of lytic solution $(10 \mathrm{mM}$ Tris $\mathrm{pH} 7.5,1 \mathrm{mM}$ EDTA, $1 \%$ SDS, $0.5 \mathrm{mg}$ proteinase $\mathrm{K}$ ). Incubations were successively extracted with equal volumes of phenol and phenolchloroform. After addition of 0.1 volume of $3 \mathrm{M}$ sodium acetate, $\mathrm{pH} 7.5$, and two volumes of ethanol, DNA was precipitated for $12 \mathrm{~h}$ at $-20^{\circ} \mathrm{C}$, pelleted by centrifugation, dried, and resuspended in water.

\section{LOH ANALYSIS}

PCR was used to amplify one dinucleotide (microsatellite) and one VTR polymorphism, both intragenic to $\mathrm{p} 53$, one dinucleotide polymorphism (L5.71) closely linked to the APC gene, and two chromosome 9p21 dinucleotide polymorphisms (D9S157 and D9S171) flanking the p16 gene. ${ }^{28-31}$ Approximately $50 \mathrm{ng}$ of genomic DNA were amplified and electrophoresed as previously described. ${ }^{32}$ Autoradiographic patterns of normal tissue and pathological tissue pairs were analysed by densitometry, and loss of heterozygosity was defined as a reduction in the signal of more than $80 \%$ in one of the alleles in the tumour tissue.
SSCP AND SEQUENCING OF P53, APC, AND P16 Primers and polymerase chain reaction (PCR) conditions for amplification of exons 5 to 8 of p53, codons 1260 to 1547 of APC, and the second exon of p16 have been described before. ${ }^{32-34}$ SSCP analysis was adapted from the original method of Orita et al. ${ }^{35}$ Briefly, $5 \mu$ of the PCR product were mixed with $50 \mu$ of formamide denaturing loading buffer and heated at $95^{\circ} \mathrm{C}$ for five minutes. Five microlitres were loaded on a $7 \%$ polyacrilamide gel containing $5 \%$ glycerol and electrophoresed at $5 \mathrm{~W}$ for 12 hours in a cooling room refrigerated at $4^{\circ} \mathrm{C}$.

Tumours showing band shifts were amplified and PCR products were purified and subjected to direct sequencing as previously described. ${ }^{32}$ Mutations were confirmed by sequencing both strands from two different amplifications.

HOMOZYGOUS DELETION OF THE P16 GENE Genomic DNA from pathological samples was simultaneously amplified (multiplex PCR) for the first exon of p16 and a sequence of the human $\mathrm{N}$-acetyltransferase 2 (NAT2) gene. Primers for exon 1 of pl 6 were GAAGAAAGAGGAGGGGCTGGCTGGTCACCA and GCGCTACCTGATTCCAATTCCCCTGCAAAC and amplified a fragment of $340 \mathrm{bp}$. Primers for the NAT2 gene were GGGGATCATGGACATTTGAAG and CTTCCCAAGATAATCACAGGCC, and amplified a sequence of $1125 \mathrm{bp}$ corresponding to nucleotides 755 to 1880 of the NAT2 sequence (EMBL accession number X14672). Reactions consisted of $100 \mathrm{ng}$ of genomic DNA, 50 pmol of each of the four primers, $200 \mu \mathrm{M}$ of each dNTP, $2.5 \mathrm{mM} \mathrm{MgCl}_{2}, 1 \times$ reaction buffer, and 1 unit of Taq polymerase in a total volume of $50 \mu \mathrm{l}$. PCR conditions consisted of an initial denaturing step of five minutes at $98^{\circ} \mathrm{C}$ followed by 20 cycles of 30 seconds at $95^{\circ} \mathrm{C}$, one minute at $62^{\circ} \mathrm{C}$ (annealing), and one minute at $72^{\circ} \mathrm{C}$ (extension). Ten microlitres of each reaction were electrophoresed overnight on a $1.5 \%$ agarose gel and subjected to Southern blot analysis following a standard protocol. Briefly, DNA was blotted onto a nylon membrane and hybridised at $42^{\circ} \mathrm{C}$ with a formamide hybridisation solution containing the p16 (first exon) and NAT1 probes radioactively labelled by random priming. After a final wash at $65^{\circ} \mathrm{C}$ with $0.1 \times$ $\mathrm{NaCl} /$ sodium citrate (SSC) $/ 0.5 \%$ sodium dodecyl sulphate (SDS), membranes were autoradiographed at $-80^{\circ} \mathrm{C}$ for $2-12$ hours.

\section{Results}

We compared the patterns for two 9p21 microsatellites (D9S171 and D9S157), one APC microsatellite, one p53 microsatellite, and one p53-VTR in DNA samples from pathological and normal tissue counterparts. DNA samples were obtained from 12 Barrett's patients without dysplasia, 15 patients with low grade dysplasia, and 14 patients with adenocarcinoma. Thirty one patients were informative for at least one of the two p53 markers and $\mathrm{LOH}$ was found in $45 \%(14 / 31)$ of them (fig 1 ). LOH was not found (0/8) in Barrett's oesophagus without dysplasia, but was present in $92 \%$ 
A

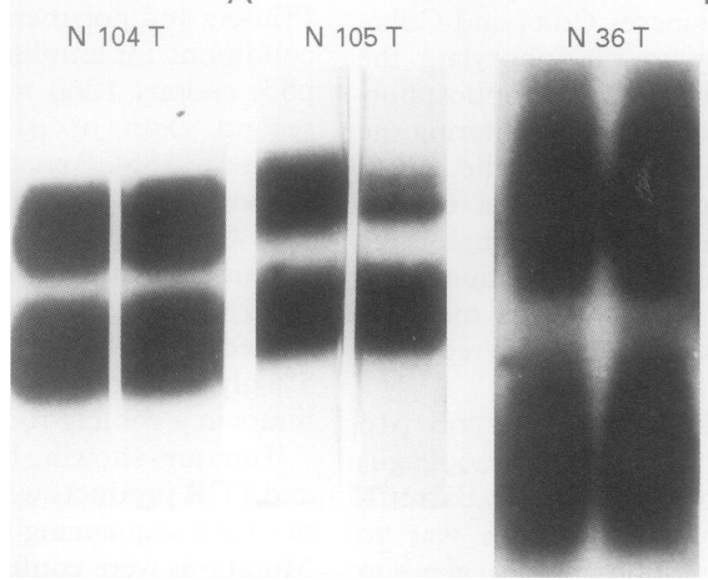

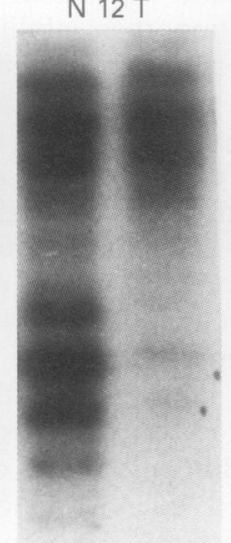

N $104 \mathrm{~T}$

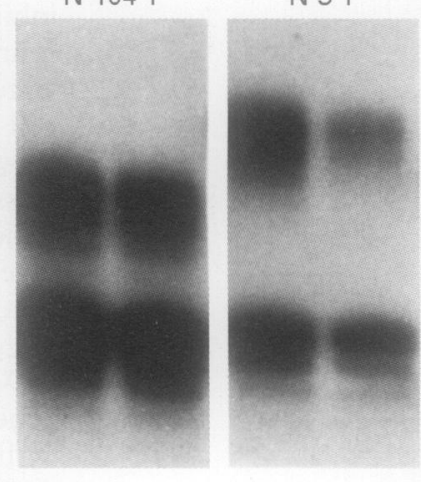

Figure 1 Positive and negative loss of heterozygosity for polymorphisms p53-VTR $(A), A P C-V T R(B)$, and D9S171 (C). Deleted alleles are characterised by a significant reduction of the signal in tumour tissue (T) DNA relative to normal tissue (N) DNA. For each marker, cases with retention of heterozygosity (left) and LOH (right) are shown.

$(11 / 12)$ of the adenocarcinomas. Similarly, $\mathrm{LOH}$ at 9 p21 increased from $0 \%(0 / 7)$ in Barrett's oesophagus negative for dysplasia to $91 \%$ $(10 / 11)$ in adenocarcinoma (fig 1). Interestingly, DNA of patient 21 was available from both the low grade dysplastic and the adenocarcinoma epithelium. In this case $\mathrm{LOH}$ at p53 and $9 \mathrm{p} 21$ was found in the adenocarcinoma, while both alleles at the p53 and 9p21 markers were retained in the low grade dysplastic epithelium.

Loss of heterozygosity at the APC gene was only found in $55 \%(6 / 11)$ of the adenocarcino- mas. All the six tumours showing $\mathrm{LOH}$ at this gene also had LOH at p53 (table 1).

SSCP analysis of exons 5 to 8 of p53 showed the presence of a mobility shift in two adenocarcinomas (exons 5 and 7) (fig 2). Direct sequencing of these cases indicated the presence of missense mutations at codon 175 (CGC:Arg $\rightarrow$ CAC:His) and at codon 245 (GGC:Gly $\rightarrow$ AGC:Ser). SSCP for codons 1260-1410 and 1389-1547 of the APC gene showed a mobility shift in the 1260-1410 segment in one case (fig 2). Direct sequencing showed a $\mathrm{T}$ deletion at codon 1297

Table 1 p53, APC, and p16 allelic losses, p53 mutations, homozygous deletion of p16

\begin{tabular}{|c|c|c|c|c|c|c|}
\hline Patient & Neoplastic stage & p53 LOH & $A P C L O H$ & $9 p 21 L O H$ & p53mut & p16del \\
\hline 102 & Barrett's & - & - & NI & - & - \\
\hline 103 & Barrett's & NI & - & NI & - & - \\
\hline 6 & Barrett's & - & NI & - & - & - \\
\hline 8 & Barrett's & - & - & NI & - & - \\
\hline 9 & Barrett's & NI & - & - & - & - \\
\hline 11 & Barrett's & - & NI & NI & - & - \\
\hline 13 & Barrett's & NI & NI & NI & - & - \\
\hline 22 & Barrett's & - & - & - & - & - \\
\hline 23 & Barrett's & NI & - & - & - & - \\
\hline 24 & Barrett's & - & - & - & - & - \\
\hline 29 & Barrett's & - & - & - & - & - \\
\hline 14 & Barrett's & - & NI & - & - & - \\
\hline 4 & LGD & NI & - & - & - & - \\
\hline 7 & LGD & + & - & - & - & - \\
\hline 14 & LGD & - & NI & - & - & - \\
\hline 16 & LGD & NI & - & NI & - & - \\
\hline 17 & LGD & NI & - & - & - & - \\
\hline 18 & LGD & - & - & - & - & - \\
\hline 112 & LGD & + & - & NI & - & - \\
\hline 113 & LGD & - & - & - & - & - \\
\hline 5 & LGD & + & NI & + & - & - \\
\hline 21 & LGD & - & NI & - & - & - \\
\hline 101 & LGD & - & NI & NI & - & - \\
\hline 19 & LGD & - & - & NI & - & - \\
\hline 20 & LGD & - & - & - & - & - \\
\hline 26 & LGD & - & NI & - & - & - \\
\hline 28 & LGD & NI & NI & - & - & - \\
\hline 111 & ADENO & + & - & + & - & - \\
\hline 21 & ADENO & + & NI & + & - & - \\
\hline 12 & ADENO & + & + & + & - & - \\
\hline 36 & ADENO & + & - & + & $+($ Exon5) & - \\
\hline 1 & ADENO & + & + & + & - & + \\
\hline 2 & ADENO & $\mathrm{NI}$ & NI & + & - & + \\
\hline 3 & ADENO & + & - & + & $+($ Exon7) & + \\
\hline 104 & ADENO & - & - & - & - & - \\
\hline 105 & ADENO & + & + & + & - & - \\
\hline 106 & ADENO & + & + & NI & - & - \\
\hline 107 & ADENO & + & + & + & - & - \\
\hline 108 & ADENO & NI & - & NI & - & - \\
\hline 109 & ADENO & + & + & NI & - & - \\
\hline 110 & ADENO & + & NI & + & - & - \\
\hline
\end{tabular}

LGD = low grade dysplasia; $\mathrm{ADENO}=$ adenocarcinoma; $\mathrm{p} 16 \mathrm{del}=$ homozygous deletion of p16; NI = not informative. 


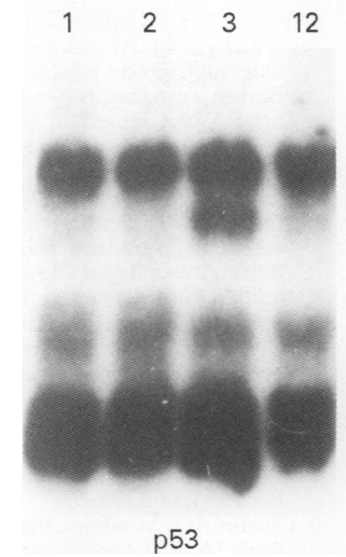

B

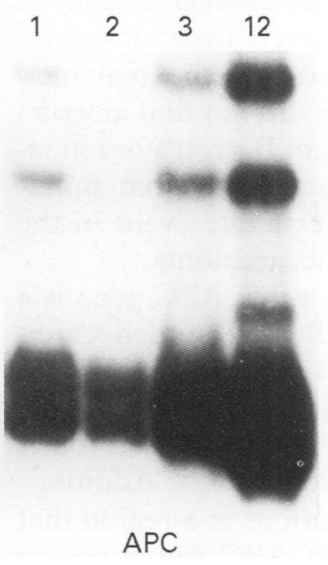

C

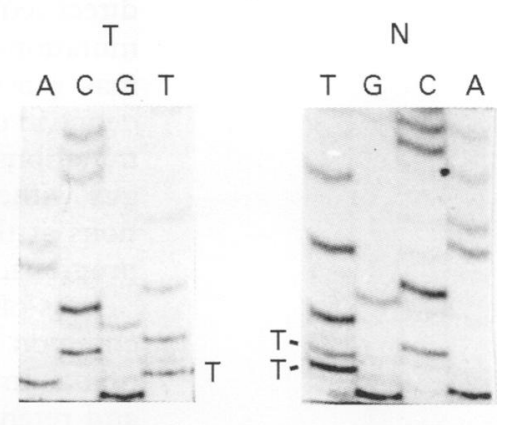

Figure 2 (A) SSCP analysis of exon 7 of p53. Tumour 3 shows a mobility shift. (B) SSCP analysis of codons 1260-1410 of the APC gene. Tumour 12 shows a mobility shift. (C) Direct sequencing of the APC gene from tumour tissue (left) and normal tissue (right) of case 12.

(ATT.CTG $\rightarrow$ ATC.TG) that introduced a frameshift.

The second exon of p16, where previous studies have located most p16 mutations, was also analysed by SSCP. We failed to detect any mobility shift, suggesting a lack of mutations at this exon in this group of patients. However, in three tumours we obtained a very faint signal. We suspected the homozygous deletion of p16 in these tumours, with the reduced amplification observed corresponding to normal nontumour "contaminating" epithelium. In some recent studies a high frequency of homozygous deletion of the p16 gene has been described in several cancer types that showed frequent $\mathrm{LOH}$ at $9 \mathrm{p} 21$. These included primary tumours with a low frequency of p16 mutations. To determine the inactivation of p16 through homozygous deletion we developed a protocol consisting of the simultaneous amplification of the first exon of p16 and a "control" sequence (NAT2) followed by Southern blot analysis. To minimise the signal from normal contaminating epithelium we reduced to 20 the number of PCR
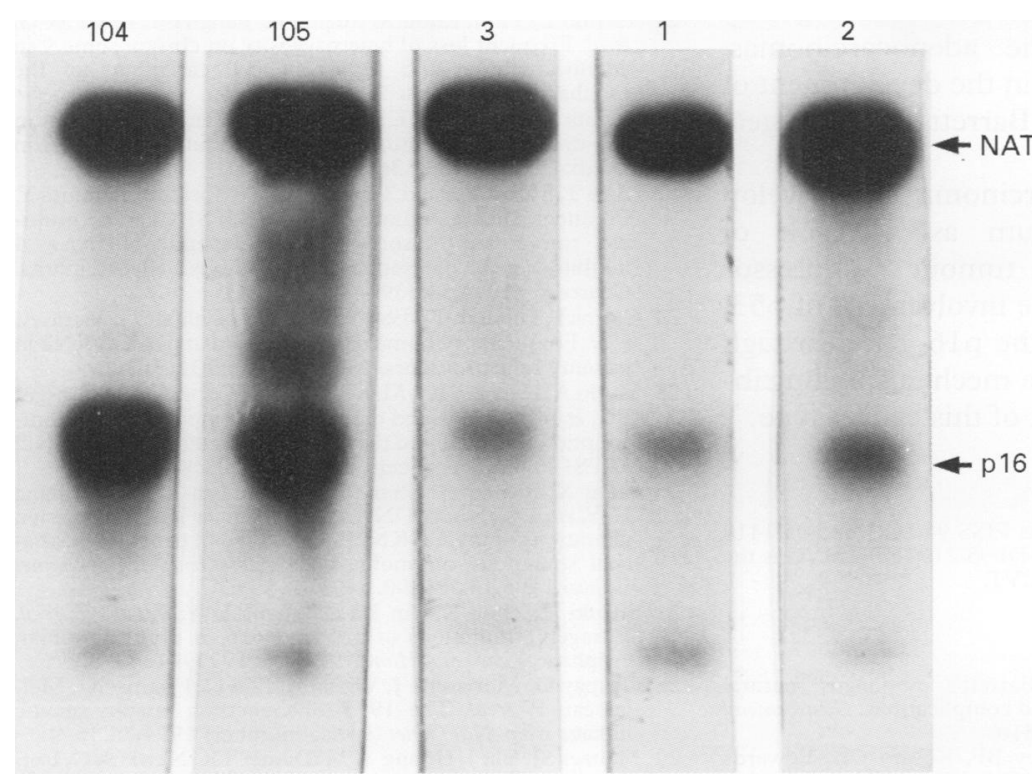

Figure 3 Southern blot analysis of the NAT2 and p16 genes. Tumours 1, 2, and 3 show a very faint 16 signal suggesting the homozygous deletion of this gene. cycles. We observed a p16 signal equivalent to that of the NAT2 sequence in 37 of the 40 samples. However, in three of the 12 adenocarcinomas the p16 autoradiographic band was absent or very faint, indicating the homozygous deletion of the gene in these patients (fig 3).

\section{Discussion}

We have analysed the role of genetic abnormalities (allelic loss and mutation) of the p16 and $\mathrm{p} 53$ genes in the progression from Barrett's epithelium to oesophageal adenocarcinoma. A high frequency of alterations at the p 53 gene, either loss of heterozygosity or mutation in exons 5 to 8 , has been found in most human cancers. ${ }^{36}$ Several investigators have described the p53-LOH in most Barrett's adenocarcinomas. We found loss of heterozygosity at this gene in $92 \%$ of adenocarcinomas and in $27 \%$ of the low grade dysplasias. However, loss of heterozygosity was not found in eight informative Barrett's oesophagus without dysplasia. Taken together these data indicate that loss of heterozygosity at the p53 gene is a genetic alteration that occurs in the transition from Barrett's epithelium to low grade dysplastic epithelium. Regarding p53 mutations, published data are contradictory, with mutation frequencies in the Barrett's adenocarcinomas varying from $10 \%$ to $100 \%$. The p53 gene was found to be mutated in two cases, representing $14 \%$ of our adenocarcinomas. Both p53 mutations, at codons 175 and 245, had been described previously in several cancer types, including Barrett's adenocarcinomas. Discrepancies in the frequencies of p53 mutations can be attributed to differences in the methodology used for the detection of mutations, such as the sets of PCR primers used for amplification of exons 5 to 8 or the type of technique (DGGE or SSCP). Compared to other studies using SSCP, we found a lower frequency of p53 mutations. We used intronic PCR primers that allowed us to amplify the complete coding sequence of exons 5 to 8 . We have previously described the SSCP analysis and direct sequencing of the p53 gene in several head and 
neck tumours. Following our SSCP protocol a total correlation was found between SSCP and direct sequencing. Thus the lower frequency of mutations found in our Barrett's adenocarcinomas most probably represents the real incidence in our tumours. We did not find any p53 mutations in the 12 cases of Barrett's oesophagus without dysplasia, suggesting that mutations at this gene occur as a late event in the progression towards adenocarcinoma.

Loss of heterozygosity at the APC gene is a common alteration in Barrett's adenocarcinoma. In no patient did we find APC-LOH and retention of both alleles at the $\mathrm{p} 53$ gene. This suggests that p53-LOH precedes or is concurrent with APC allelic losses. Additionally, we searched for mutations at a region that contains the hot spots of APC mutations in colorectal tumours. ${ }^{37}$ In accordance with the two hit model for tumour suppressor gene inactivation, one adenocarcinoma showed both APC-LOH and a mutation in the APC retained allele. We only analysed part of exon 15 , so the rate of APC mutations in Barrett's adenocarcinoma could be higher than that described here. In addition, the MCC gene, closely linked to APC on chromosome $5 \mathrm{q}$ could be the target for mutations in tumours with loss of heterozygosity at this region.

Loss of heterozygosity at $9 \mathrm{p} 21$ occurs at a high frequency in several human cancers, including adenocarcinoma of the oesophagus. ${ }^{21}$ This chromosome region contains the p16 gene which has the properties of a tumour suppressor gene. The p16 gene has been found deleted and mutated at a high frequency in human cancer cell lines, which is the reason why it was named multiple tumour suppressor 1 (MTS-1). However, p16 mutations are much less frequent in primary tumours. Homozygous deletion and loss of expression through methylation of a $\mathrm{CpG}$ island located at the 5 ' end of the gene have been recently described as the main mechanisms for the absence of the p16 protein in primary tumours. Our results showed the absence of p16 mutations in tumour tissue. This gene was homozygously deleted in $25 \%$ of the adenocarcinomas, suggesting a role for p16 in the development of a significant number of Barrett's oesophageal adenocarcinomas.

Oesophageal adenocarcinoma can develop from Barrett's epithelium as a result of alterations at several tumour suppressor genes. ${ }^{38}$ In addition to the involvement of $\mathrm{p} 53$, we describe the loss of the p16 gene through homozygous deletion as a mechanism contributing to the development of this cancer type.

This work was supported by grants FISS 94/1421 and 96/1418 (EC) and Universidad de Oviedo-DF95/219 (RP). MVG is the recipient of a fellowship of the FiCYT.

1 Phillips RW, Wong RKH. Barrett's esophagus: natura history, incidence, etiology and complications. Gastroentero history, incidence, etiology and com
Clin North Am 1991;20:791-816.

2 Miller BA, Ries LAG, Hankey BF, Kosary CL, Edwards BK. Cancer statistics review, 1973-1989. NIH Publication No 92-2789. Bethesda MD: US Department of Health and Human Services.
3 Levine DS, Reid BJ. Endoscopic diagnosis of esophageal neoplasms. In: Sivak M, ed. Gastrointestinal endoscopy clinics orth America. Philadelphia: WB Saunders, 1992:395413.

4 Levine DS, Haggitt RC, Blount PL, Rabinovitch PS, Rusch VW, Reid BJ. An endoscopic biopsy protocol can differentiate high grade dyplasia from early adenocarcinoma in Barrett's esophagus. Gastroenterology 1993;105:40-50.

5 Rusch VW, Levine DS, Haggitt RC, Reid BJ. The management of high grade dysplasia and early cancer in Barrett's ment of high grade dysplasia and early

6 Reid BJ, Weinstein WM, Lewin KJ, Haggitt RC, Van Deventer G, Denbesten L, et al. Endoscopic biopsy can detect high-grade dysplasia or early adenocarcinoma in Barrett's esophagus without grossly recognizable neoplastic lesions. Gastroenterology 1988;94:81-90.

7 Blount PL, Ramel S, Raskind WH, Haggitt RC, Sanchez $\mathrm{CA}$, Dean PJ, et al. $17 \mathrm{p}$ allelic deletions and p53 protein overexpression in Barrett's adenocarcinoma. Cancer Res 1991:51:5482-6.

8 Blount PL, Galipeau PC, Sanchez CA, Neshat K, Levine $\mathrm{DS}$, Yin J, et al. 17p allelic losses in diploid cells of patients with Barrett's esophagus who develop aneuploidy. Cancer Res 1994;54:2292-5.

9 Casson AG, Mukhopadhyay T, Cleary KR, Ro JY, Levin B, Roth JA. p53 gene mutations in Barrett's epithelium and esophageal cancer. Cancer Res 1991;51:4495-9.

10 Neshat K, Sanchez CA, Galipeau PC, Blount PL, Levine DS, Joslyn G, et al. p53 mutations in Barrett's adenocarcinoma and high-grade dysplasia. Gastroenterology 1994;106: noma and

11 Huang Y, Meltzer SJ, Yin J, Tong Y, Chang EH, Srivastava $\mathrm{S}$, et al. Altered messenger RNA and unique mutational profiles of $\mathrm{p} 53$ and $\mathrm{Rb}$ in human esophageal carcinomas. Cancer Res 1993;53:1889-94.

12 Greenwald BD, Huang Y, Baum R, Meltzer SI. Barrett's carcinoma in a 25 year old man with point mutation of the p53 tumor suppressor gene. Int 7 Oncol 1992;1:271-5.

13 Hamelin R, Flejou JF, Muzeau F, Potet F, Laurent-Puig P, Fékété $\mathrm{F}$, et al. TP53 gene mutations and p53 protein immunoreactivity in malignant and premalignant Barrett's esophagus. Gastroenterology 1994;107:1012-8.

14 McKinley MJ, Budman DR, Grueneberg D, Bronzo RL Wissman GS, Kahn E. DNA content in Barrett's esophagus and esophageal malignancy. $A m \mathcal{F}$ Gastroenterol 1987;82:1012-5.

15 Reid BJ, Blount PL, Robin CE, Levine DS, Haggitt RC Rabinovitch PS. Flow-cytometric and histological progression to malignancy in Barrett's esophagus: prospective sion to malignancy in Barrett's esophagus: prospective 102:1212-9.

16 Rabinovitch PS, Reid BJ, Haggitt RC, Norwood TH, Rubin CE. Progression to cancer in Barrett's esophagus is associated with genomic instability. Lab Invest 1988;60:65-71.

17 Fearon ER, Vogelstein B. A genetic model for colorectal tumorigenesis. Cell 1990;61:759-67.

18 Huang Y, Boynton RF, Blount PL, Silverstein RJ, Yin J, Tong Y, et al. Loss of heterozygosity involves multiple Tong Y, et al. Loss of heterozygosity involves multiple tumor suppressor genes in hur

19 Blount PL, Meltzer SJ, Yin J, Huang Y, Krasna MJ, Reid BJ. Clonal ordering of $17 \mathrm{p}$ and $5 \mathrm{q}$ allelic losses in Barrett dysplasia and adenocarcinoma. Proc Natl Acad Sci USA 1993; 90:3221-5.

$20 \mathrm{Kamb}$ A, Gruis NA, Weaver-Feldhaus J, Liu Q, Harshman $\mathrm{K}$, Tavtigian SV, et al. A cell cycle-regulator potentially involved in the genesis of many tumor types. Science 1994; 264:436-40.

21 Tarmin L, Yin J, Zhou X, Suzuki H, Jiang H-Y, Rhyu M-G, et al. Frequent loss of heterozygosity on chromosome 9 in adenocarcinoma and squamous cell carcinoma of the esophagus. Cancer Res 1994;54:6094-6.

22 Serrano M, Hannon G, Beach D. A new regulatory motif in cell-cycle control causing specific inhibition of cyclin D/cdk4. Nature 1994;366:704-7.

23 Mori T, Miura K, Aoki T, Nishihira T, Mori S, Nakamura Y. Frequent somatic mutations of the MTS1/CDK4I (multiple tumor suppressor $1 /$ cyclin-dependent kinase 4 ple tumor suppressor $1 /$ cyclin-dependent kinase 4 Cancer Res 1994;54:3396-7.

24 Cairns P, Polascik TJ, Eby Y, Tokino K, Califano J, Merlo A, et al. Frequency of homozygous deletion at p16/CDKN2 in primary human tumors. Nat Genet 1995;11:210-2.

25 Merlo A, Herman JG, Mao L, Lee DJ, Gabrielson E, Burger $\mathrm{PC}$, et al. 5' $\mathrm{CpG}$ island methylation is associated with transcriptional silencing of the tumor suppressor p16/CDKN2/ MTS1 in human cancers. Nat Med 1995;1:686-92. 26 Zhou X, Suzuki H, Shimada Y, Imamura M, Yon J, Jiang alterations of the CDKN2B and CDKN2 genes in esophageal squamous carcinoma cell lines. Genes Chromosomes Cancer 1995;13:285-90.

27 Suzuki H, Zhou X, Yin J, Lei J, Jiang H-Y, Suzuki Y, et al. Intragenic mutations of p15 and p16 in primary human esophageal cancers. Hum Mol Genet 1995;4:1883-8.

28 Gyapay G, Morissette J, Vignal A, Dib C, Fizames C, Mellasseau P, et al. The 1993-94 Généthon human genetic lasseau $P$, et al. The 1993-94 Genethon human genetic
linkage map. Nat Genet (special number) 1994;7:246-9.

9 Meltzer SJ, Yin J, Huang Y, McDaniel TK, Newkirk C, Iseri $\mathrm{O}$, et al. Reduction of homozygosity involving p53 in esophageal cancers demonstrated by polymerase chain reaction. Proc Natl Acad Sci USA 1991;88:4976-80. 
30 Futreal PA, Barret JC, Wiseman RW. An Alu polymorphism intragenic to the TP53 gene. Nucleic Acids Res 1991;19: 6977.

31 Jones MH, Sato T, Tangami A, Nakamura Y. Six microsatellite polymorphisms at candidate and confirmed tumor suppressor gene loci. Hum Mol Genet 1994;3:1991.

32 González MV, Pello MF, López-Larrea C, Suárez C, Menéndez MJ, Coto E. Loss of hoterozygosity and mutation analysis of the p16 (9p21) and p53 (17p13) genes in squamous cell carcinoma of the head and neck. Clin Cancer Res 1995;1:1043-9.

33 Tamura G, Maesawa C, Suzuki Y, Tamada H, Satoh M, Ogasawara S, et al. Mutations of the APC gene occur during early stages of gastric adenoma development. Cancer ing early stages of gas

34 Marchetti A, Buttitta F, Pellegrini S, Campani D, Diella F,
Cecchetti D, et al. Mutations and histological type of invasive breast carcinoma. Cancer Res 1993;53:4665-9.

35 Orita M, Suzuki Y, Sekiya T, Hayashi K. Rapid and sensitive detection of point mutations and DNA polymorphisms using the polymerase chain reaction. Genomics 1989;5:874 9.

36 Hollstein M, Sidransky D, Vogelstein B, Harris CC. p53 mutations in human cancers. Science 1991;253:49-53.

37 Miyoshi Y, Ando H, Nagase H, Nishisho I, Horii A, Miki Y, et al. Germ-line mutations of the APC gene in 53 familial adenomatous polyposis patients. Proc Natl Acad Sci USA 1992;89:4452-6.

38 Neshat K, Sanchez CA, Galipeau PC, Cowan DS, Ramel S, Levine DS, et al. Barrett's esophagus: a model of human neoplastic progression. In: Cold Spring Harbour symposia on quantitative biology, vol 59. Cold Spring Harbour Laboraquantitative biology, vol 59.
tory Press, 1994:577-83. 